Петр Матвеевич Мазуркин,

зав. кафедрой природообустройства,

Поволжский государственный технологический университет, проф., д-р техн. наук, академик ЕАЕ, РАЕ и РАЕН, 424036, ул. Комсомольская, 92А, 69, г. Йошкар-Ола, Республика Марий Эл, тел. (8362)686011, (8362)420774, 8-964-860-80-25, E-mail: kaf_po@mail.ru

Анастасия Игоревна Кудряшова, магистрант 2 курса 120700.68 «Землеустройство и кадастры», Александр Николаевич Фадеев, доц., канд. техн. наук, кафедра природообустройства ПГТУ

\title{
Распределения кадастровых кварталов по подзонам жилой зоны города
}

Аннотация На четырех подзонах жилой зоны города Йошкар-Ола показаны высоко адекватные закономерности в виде суммы вейвлетов распределения координат центров кадастровых кварталов. Приведены графики составляющих и модули расстояний поперек реки по широте.

Abstract Four sub-zone residential zone of the city Yoshkar-Ola shown highly adequate laws as a sum of wavelets distribution of the coordinates of the centers of cadastral districts. The graphs of components and modules distances across the river in latitude.

Ключевые слова: город, жилые подзоны, квартала, центры, координаты, закономерности

Keywords: city, residential subzone, quarter, centers, coordinates, patterns

Введение. Закономерности распределения кадастровых кварталов зависят также и от количества и качества элементов растительного покрова [1-9]. Цель статьи - выявление и сравнение многочленных закономерностей, а также показать возможность статистического моделирования трендами и асимметричными вейвлетами, распределений кадастровых кварталов по подзонам жилой зоны на примере города Йошкар-Ола, столицы Республики Марий Эл.

Генеральный план городского округа "Город Йошкар-Ола" - столицы Республики Марий Эл - разработан в 2004 - 2007 гг. Он ставит задачу создать "экологическую и спортивную столицу" Поволжья и для этого есть все основания - красивый, чистый, активно развивающийся город. Йошкар-Ола вполне может стать умной и зеленой средой обитания .

Из Генерального плана города нами был выделена основная часть в количестве 303 кадастровых кварталов, по которым в ГИС «Карта-2011» были выделены условные координаты, периметр и площадь квартала в урезанной местной системе координат МСК-12. Основная зона города - это жилые городские квартала, требующие научного обоснования экологических мер.

Исходные данные. По таблице 1 данные по жилой зоне приведены в таблице 2.

Таблица 1. Функциональные подзоны жилой зоны города Йошкар-Ола

\begin{tabular}{|c|l|c|}
\hline Код & \multicolumn{1}{|c|}{ Наименование } & Обозначение \\
\hline 11 & Зона застройки многоэтажными жилыми домами (61) & \\
\hline 12 & Зона застройки мало и средне этажными жилыми домами (11) & $\square$ \\
\hline 13 & Зона застройки индивидуальными жилыми домами (46) & $\square$ \\
\hline 14 & Зона садово-дачных участков (6) & $\square$ \\
\hline
\end{tabular}

В таблице 2 приведены условные обозначения координат центров кадастровых кварталов:

$x$ - условная координата центра кадастрового квартала по широте Y (абсцисса), м, 
$y$ - условная координата центра кадастрового квартала по долготе X (ордината), м.

Из ГИС «Карта-2011» были получены данные: $P$ - периметр кадастрового квартала, м; $S$ -

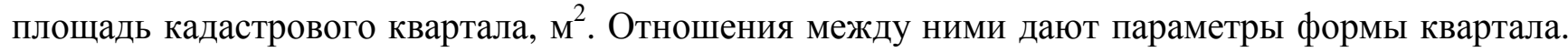
Для дальнейшей оценки формы кадастровых кварталов в таблице 2 даны также параметры абсолютной формы $S / P$ и относительной формы $100 S / P^{2}$.

Таблица 2. Данные по 124 кадастровым кварталам жилой зоны города

\begin{tabular}{|c|r|r|r|r|r|r|r|}
\hline \multirow{2}{*}{$\begin{array}{c}\text { № } \\
\text { П/п }\end{array}$} & $\begin{array}{c}\text { Код } \\
\text { Под- } \\
\text { 3оны }\end{array}$ & \multicolumn{2}{|c|}{$\begin{array}{c}\text { Координаты } \\
\text { центра квартала }\end{array}$} & \multicolumn{2}{c|}{$\begin{array}{c}\text { Параметры } \\
\text { квартала }\end{array}$} & \multicolumn{2}{|c|}{$\begin{array}{c}\text { Параметр формы } \\
\text { квартала }\end{array}$} \\
\hline 1 & 11 & 4087 & 10090 & 1440 & 113639 & 78.94 & 5.48 \\
\hline 2 & 11 & 8578 & 10552 & 1184 & 80294 & 67.81 & 5.73 \\
\hline 3 & 11 & 9335 & 11373 & 1475 & 107570 & 72.95 & 4.95 \\
\hline 4 & 11 & 9042 & 10861 & 1631 & 157486 & 96.56 & 5.92 \\
\hline 5 & 11 & 4969 & 10083 & 2170 & 164374 & 75.74 & 3.49 \\
\hline$\ldots$ & $\ldots$ & $\ldots$ & $\ldots$ & $\ldots$ & $\ldots$ & $\ldots$ & $\ldots$ \\
\hline 120 & 14 & 10472 & 9818 & 3780 & 689586 & 182.42 & 4.83 \\
\hline 121 & 14 & 10288 & 9337 & 2182 & 117193 & 53.71 & 2.46 \\
\hline 122 & 14 & 5431 & 6239 & 2451 & 288328 & 117.66 & 4.80 \\
\hline 123 & 14 & 4622 & 4981 & 3510 & 515485 & 146.85 & 4.18 \\
\hline 124 & 14 & 10983 & 8966 & 2492 & 276362 & 110.89 & 4.45 \\
\hline
\end{tabular}

Асимметричный вейвлет-сигнал для моделирования [1-8] имеет вид

$$
y_{i}=A_{i} \cos \left(\pi x / p_{i}-a_{8 i}\right),
$$

$A_{i}=a_{1 i} x^{a_{2 i}} \exp \left(-a_{3 i} x^{a_{4 i}}\right), p_{i}=a_{5 i}+a_{6 i} x^{a_{7 i}}$,

где $y$ - показатель (зависимый фактор), $x$ - объясняющая переменная (влияющий фактор), $a_{1} \ldots a_{8}$ - параметры, принимающие числовые значения в ходе идентификации (1), $A_{i}$ - амплитуда (половина) вейвлета (ось $y$ ), $p_{i}$ - полупериод волны возмущения (ось $x$ ).

Закономерности многоэтажной застройки. Модель (1) с параметрами для подзоны застройки многоэтажными жилыми домами дана в таблице 3, и по вычислительным возможностям программной среды CurveExpert-1.40 (рис. 1) она имеет вид

$$
\begin{gathered}
y=y_{1}+y_{2}+y_{3}+y_{4}+y_{5}, \\
y_{1}=10326,061, y_{2}=-0,00026285 x^{1,66346}, \\
y_{3}=-974,39238 \exp \left(1,02839 \cdot 10^{-5} x\right) \cos (\pi x / 2560,8729-1,18579), \\
y_{4}=-9,67566 \cdot 10^{-46} x^{14,04742} \exp (-0,0020142 x) \cos (\pi x / 37,42643-0,47262), \\
y_{5}=-2,87913 \cdot 10^{-10} x^{4,72522} \exp (-0,0033264 x) \cos (\pi x / 63,91849-2,30123) .
\end{gathered}
$$

Дополнительные вейвлеты появляются по остаткам от предыдущего колебания (рис. 1, рис. 2). Поэтому адекватность общей модели станет выше коэффициента корреляции формулы (2), равного 0,7716 и относящегося к уровню «сильная связь». Всего было получено 18 составляю- 
щих общей модели (1). Дальше процесс идентификации биотехнической функции (1) практически невозможен из-за того, что остатки превращаются в некий трудно разложимый «шум». Для устранения этого шума нужно снижать погрешность измерений кадастровых кварталов.

Таблица 3. Параметры (1) по кадастровым кварталам жилой зоны г. Йошкар-Ола

\begin{tabular}{|c|c|c|c|c|c|c|c|c|c|}
\hline \multirow{3}{*}{$\begin{array}{l}\text { Ho- } \\
\text { мep } \\
i\end{array}$} & \multicolumn{8}{|c|}{ Асимметричный вейвлет $y_{i}=a_{1 i} x^{a_{2 i}} \exp \left(-a_{3 i} x^{a_{4 i}}\right) \cos \left(\pi x /\left(a_{5 i}+a_{6 i} x^{a_{7 i}}\right)-a_{8 i}\right)$} & \multirow{3}{*}{$\begin{array}{c}\text { Коэфф } \\
\text { коррел } \\
r\end{array}$} \\
\hline & \multicolumn{4}{|c|}{ амплитуда (половина) колебания } & \multicolumn{3}{|c|}{ полупериод колебания } & \multirow{2}{*}{$\begin{array}{c}\text { сдвиг } \\
a_{8 i}\end{array}$} & \\
\hline & $a_{1 i}$ & $a_{2 i}$ & $a_{3 i}$ & $a_{4 i}$ & $a_{5 i}$ & $a_{6 i}$ & $a_{7 i}$ & & \\
\hline \multicolumn{10}{|c|}{ Зона застройки многоэтажными жилыми домами } \\
\hline 1 & 10326,061 & 0 & 0 & 0 & 0 & 0 & 0 & 0 & \multirow{5}{*}{0,7716} \\
\hline 2 & $-0,00026285$ & 1,66346 & 0 & 0 & 0 & 0 & 0 & 0 & \\
\hline 3 & $-974,39238$ & 0 & $-1,02839 \mathrm{e}-5$ & 1 & 2560,8729 & 0 & 0 & 1,18579 & \\
\hline 4 & $-9,67566 e-46$ & 14,04742 & 0,0020142 & 1 & 37,42643 & 0 & 0 & 0,47462 & \\
\hline 5 & $-2,87913 \mathrm{e}-10$ & 4,72522 & 0,0033264 & 1 & 63,91849 & 0 & 0 & 2,20123 & \\
\hline 6 & $1,76187 \mathrm{e}-77$ & 25,37674 & 0,0050400 & 1,03744 & 126,81852 & $-0,0056969$ & 0,93548 & $-1,22816$ & 0,2064 \\
\hline 7 & $2,34746 \mathrm{e}-144$ & 40,73151 & 0,0037395 & 0,99974 & 50,75382 & 0 & 0 & $-1,27406$ & 0,4529 \\
\hline 8 & 298,64261 & 0 & 0 & 0 & 455,22838 & 0,00018211 & 1,28448 & 3,43749 & 0,4018 \\
\hline 9 & $-9,31265 e-88$ & 29,20884 & 0,0096720 & 0,99158 & 208,76609 & $-0,096721$ & 0,76593 & $-3,44649$ & 0,4017 \\
\hline 10 & 114,74000 & 0 & $-5,77197 e-5$ & 1 & 966,88200 & 0 & 0 & $-0,53680$ & 0,2861 \\
\hline 11 & $-4,13542 \mathrm{e}-24$ & 7,29826 & 0,00074564 & 0,99859 & 30,10116 & 0 & 0 & $-1,12517$ & 0,4589 \\
\hline 12 & $-4,44414 \mathrm{e}-26$ & 8,94554 & 0,0025927 & 1 & 50,44901 & 0 & 0 & $-1,44391$ & 0,2876 \\
\hline 13 & $1,24025 \mathrm{e}-25$ & 8,40620 & 0,0015998 & 1,00599 & 7,99736 & 0 & 0 & 0 & 0,3759 \\
\hline 14 & $6,28076 \mathrm{e}-37$ & 10,76020 & 0,00097300 & 1 & 15,08273 & 0 & 0 & $-3,23566$ & 0,4762 \\
\hline 15 & $-2,92598 \mathrm{e}-8$ & 3,37653 & 0,0014353 & 0,99971 & 35,64181 & 0 & 0 & $-5,14857$ & 0,3619 \\
\hline 16 & $-95,37454$ & 0 & $-5,13495 \mathrm{e}-5$ & 1 & 308,92427 & 0,0036414 & 1 & 2,99605 & 0,3448 \\
\hline 17 & $4,19494 \mathrm{e}-42$ & 13,66885 & 0,0027397 & 0,99817 & 4,22891 & 0,081214 & 1 & 2,13058 & 0,3224 \\
\hline 18 & 2,56711e-23 & 7,44425 & 0,0012192 & 0,99988 & 786,7405 & $-0,0095561$ & 0,99998 & $-2,71173$ & 0,4346 \\
\hline \multicolumn{10}{|c|}{ Зона застройки мало и средне этажными жилыми домами } \\
\hline 1 & 11200,478 & 0 & 0 & 0 & 0 & 0 & 0 & 0 & \multirow{3}{*}{0,9609} \\
\hline 2 & $4,57777 \mathrm{e}-136$ & 34,26625 & 0 & 0 & 0 & 0 & 0 & 0 & \\
\hline 3 & $-6,87315 e-96$ & 32,40892 & 0,010776 & 1,00311 & 645,07738 & 0 & 0 & 2,41219 & \\
\hline \multicolumn{10}{|c|}{ Зона застройки индивидуальными жилыми домами } \\
\hline 1 & $\mid-145606,893$ & 0 & 0 & 0 & 0 & 0 & 0 & 0 & \multirow{5}{*}{0,8695} \\
\hline 2 & 133282,017 & 0,018109 & 0 & 0 & 0 & 0 & 0 & 0 & \\
\hline 3 & $-3093,40746$ & 0 & 0 & 0 & 1070.2133 & 0,0022140 & 1,38727 & 3,53426 & \\
\hline 4 & $\mid-2,16535 \mathrm{e}-95$ & 31,41117 & 0,0083819 & 1 & 489,00766 & 0 & 0 & 0,74711 & \\
\hline 5 & $2,01387 \mathrm{e}-85$ & 28,08977 & 0,0072397 & 0,99942 & 287,48554 & $-0,0036619$ & 1,13629 & $-3,35068$ & \\
\hline 6 & $4,98169 \mathrm{e}-132$ & 36,76650 & 0,0029189 & 0,99949 & 298,68448 & 0 & 0 & 5,69066 & 0,4921 \\
\hline 7 & $3,02249 \mathrm{e}-21$ & 6,68855 & 0,00079635 & 0,98020 & 1053,60802 & 0 & 0 & $-2,89999$ & 0,6240 \\
\hline 8 & $1,06857 \mathrm{e}-60$ & 17,86100 & 0,0019391 & 0,99640 & 41,42186 & 0 & 0 & 4,67403 & 0,5834 \\
\hline 9 & $-3,08441 \mathrm{e} 6$ & 0 & 0,0027355 & 1 & 84,63456 & 0,073522 & 1,10818 & 0,72160 & 0,6453 \\
\hline 10 & $-1,25110 \mathrm{e}-69$ & 19,73954 & 0,0016170 & 0,99953 & 188,92293 & 0 & 0 & 0,49930 & 0,6784 \\
\hline 11 & $1,06827 \mathrm{e}-58$ & 18,46345 & 0,0034858 & 1 & 5415,6920 & $-0,33244$ & 1 & 2,35479 & 0,3466 \\
\hline 12 & $4,89380 \mathrm{e}-108$ & 33,68894 & 0,0065819 & 1 & 30,17227 & 0 & 0 & $-1,34013$ & 0,5270 \\
\hline \multicolumn{10}{|c|}{ Зона садово-дачных участков } \\
\hline 1 & $8,44488 \mathrm{e}-10$ & 3,66910 & 0,00037550 & 0,99996 & 0 & 0 & 0 & 0 & \multirow{2}{*}{1,0000} \\
\hline 2 & 0,0020020 & 1,84433 & 0,00042064 & 1 & 618,85012 & 0 & 0 & 3,56137 & \\
\hline
\end{tabular}

Первая составляющая (2) является постоянным членом, показывающим среднестатистическое значение ординаты (расстояние по долготе) в зависимости от условного от МСК-12 расстояния по широте. 


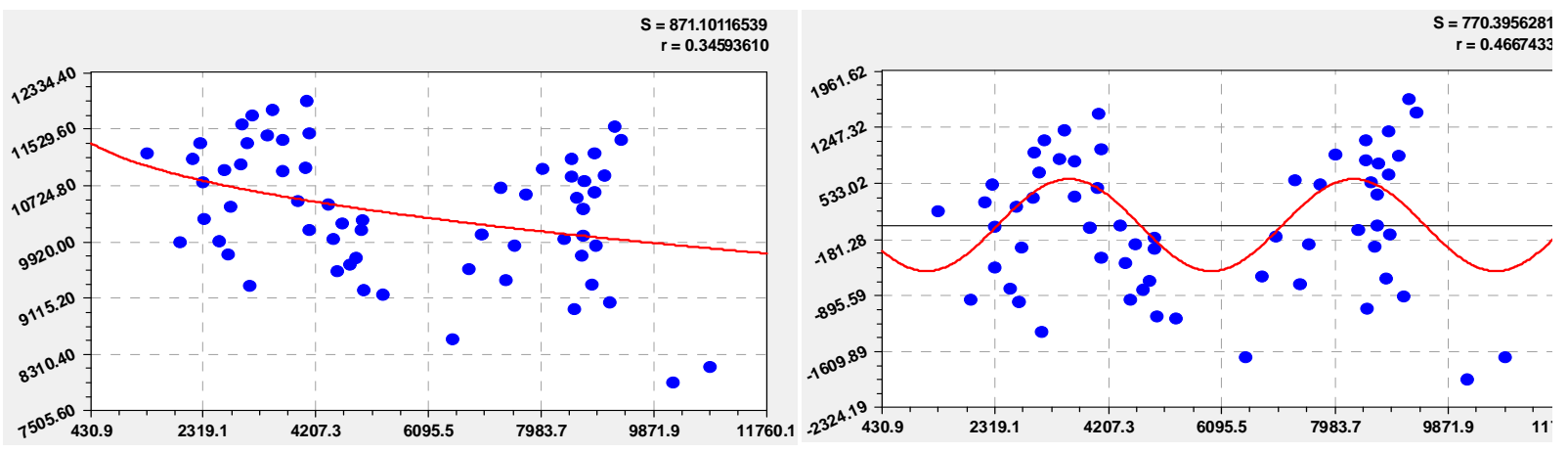

Двухчленный тренд

Первое колебание

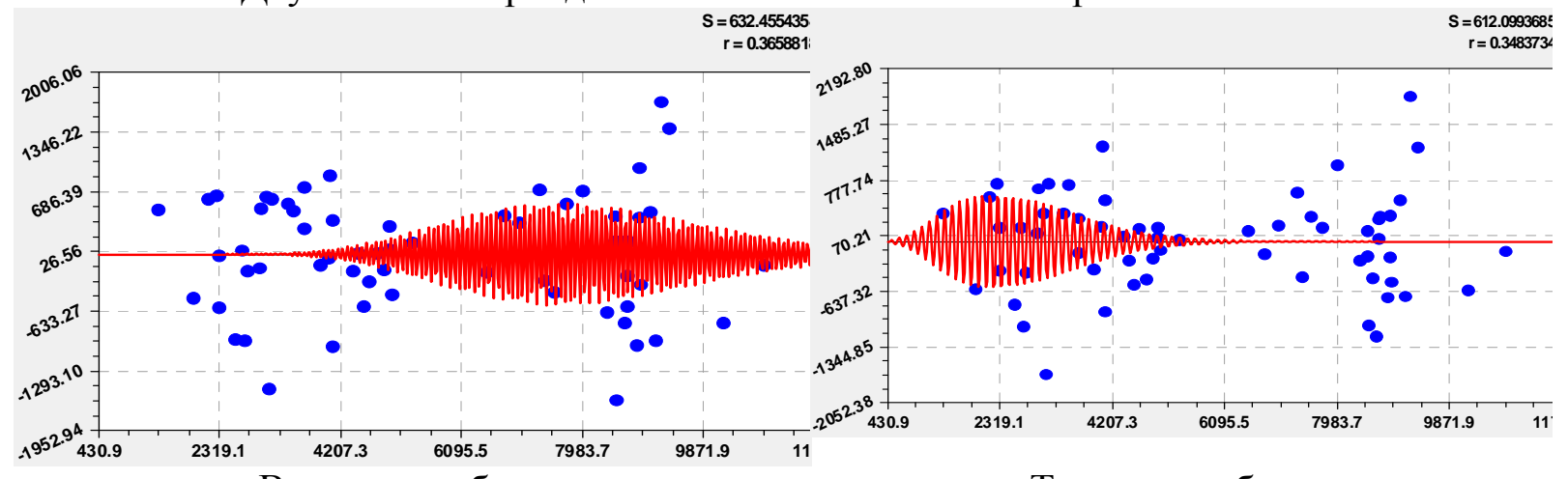

Второе колебание

Третье колебание

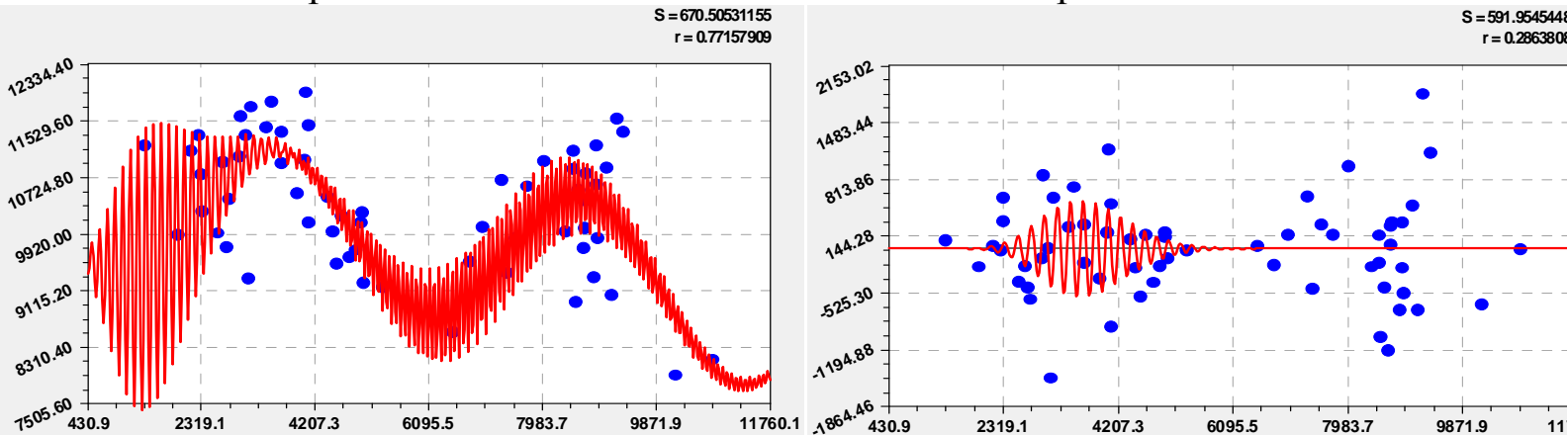

График модели (2)

Четвертое колебание $S=516.84356979$
$r=0.45294662$

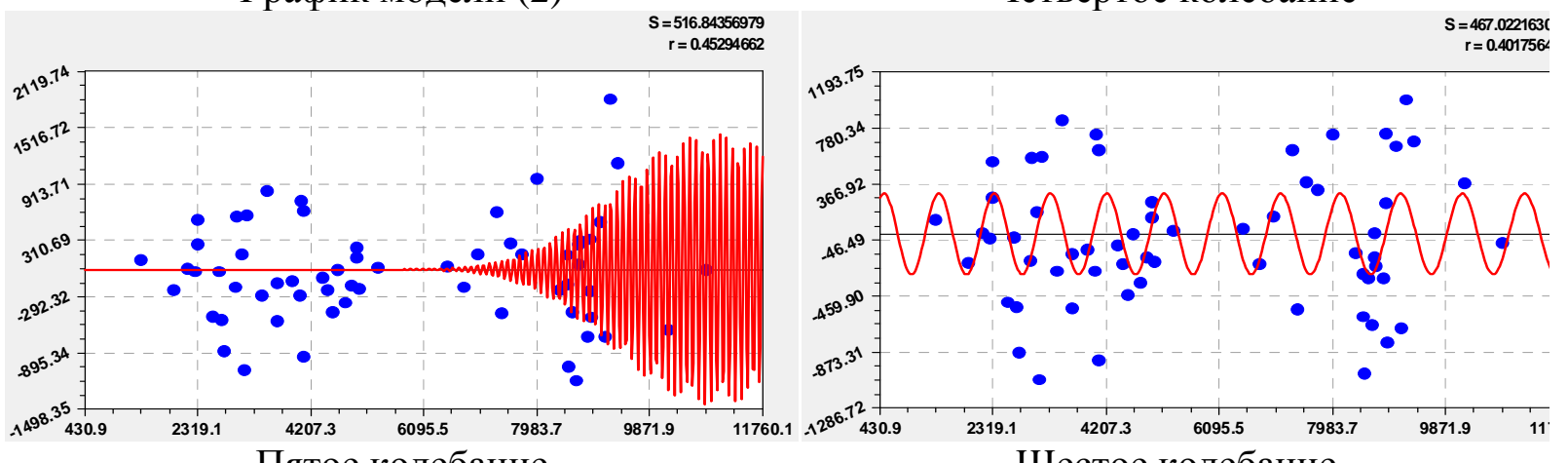
Пятое колебание

Шестое колебание

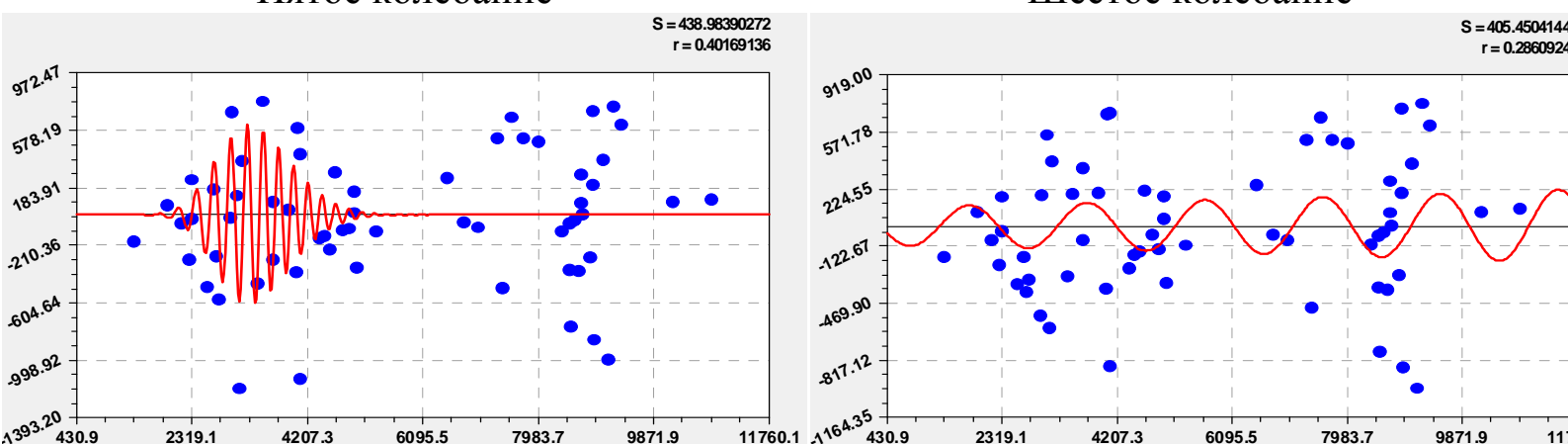

Седьмое колебание

Восьмое колебание

Рисунок 1. Графики составляющих закономерности по многоэтажной застройке 

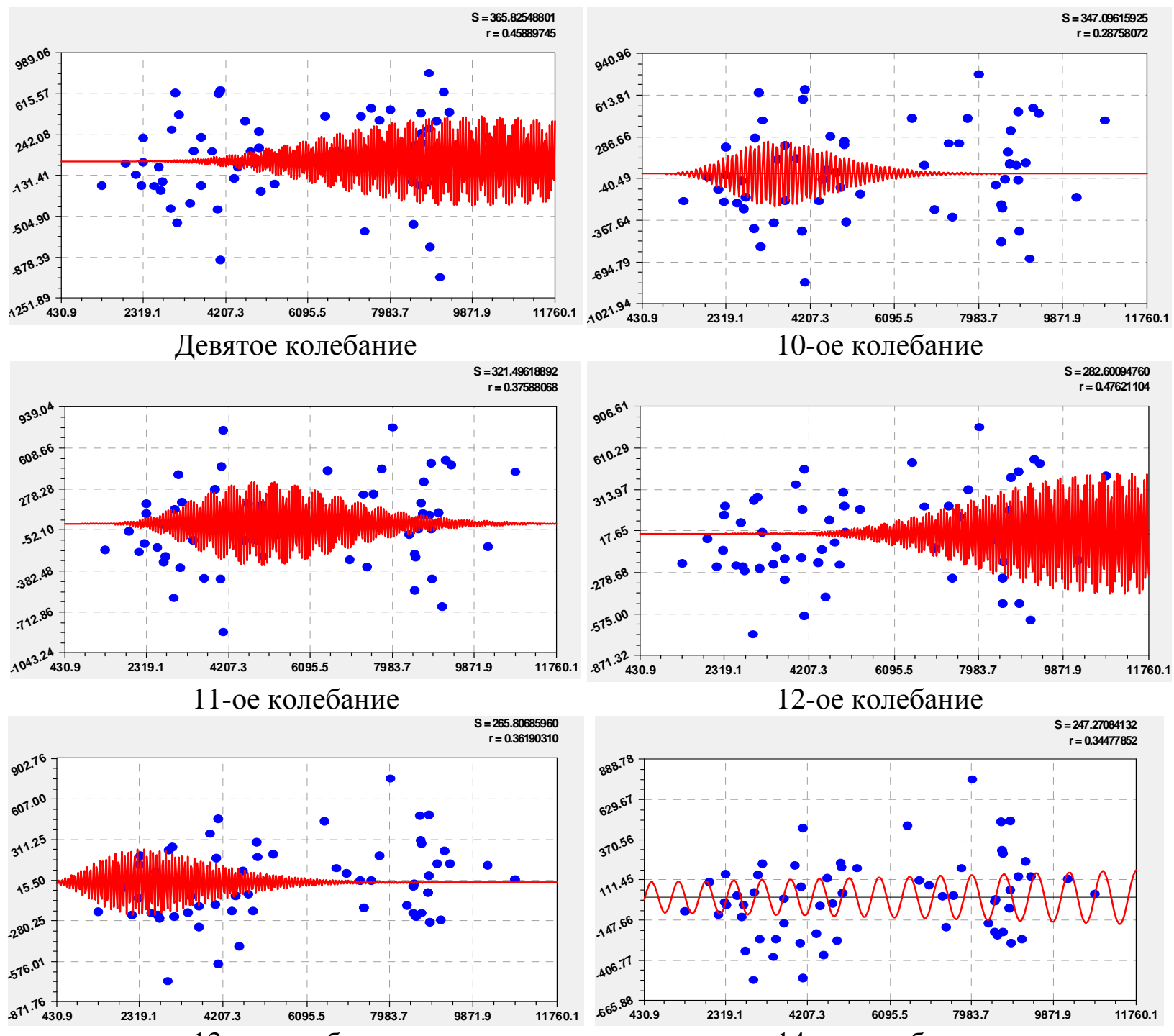

13-ое колебание

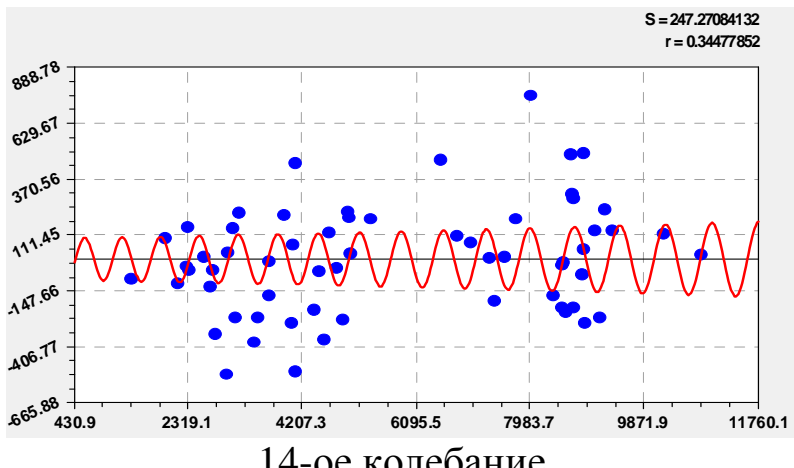

14-ое колебание

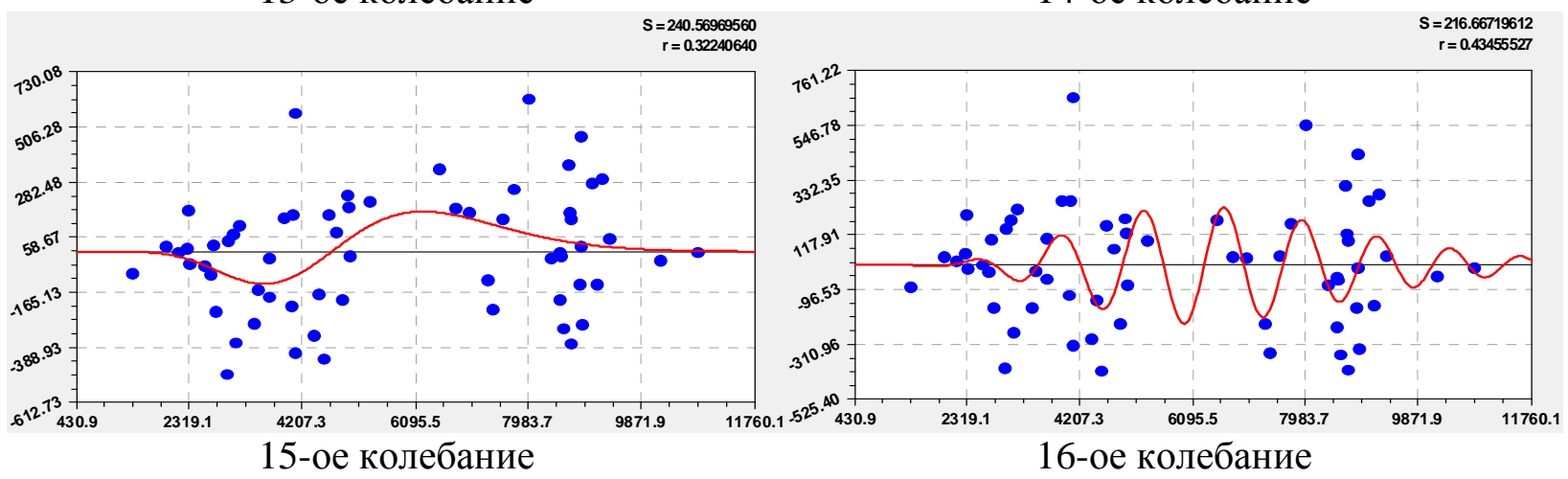

Рисунок 2. Дополнительные вейвлет-сигналы многоэтажной застройки города Йошкар-Ола

По сути - это некий архитектурный трансект расположения поперек реки Малая Кокшага кадастровых кварталов города Йошкар-Ола по многоэтажной застройке.

Наиболее точно, причем всего двумя членами модели (1), характеризуется распределение кадастровых кварталов зоны садово-дачных участков. При этом тренд характеризуется биотехническим законом, то есть четвертая зона расположена в городской черте удачно. Затем на втором месте находится зона застройки мало и средне этажными жилыми домами. Высокая адекватность волн наблюдается в зоне застройки индивидуальными жилыми домами. И, наконец, 
много волн у (1) по многоэтажной застройке. Это значит, что за 40 лет развития города распределение многоэтажек выполнялось хаотично, интуитивно, без достаточного ландшафтноматематического обоснования.

Из рисунков 1 и 2 видно, что по полупериоду поперек реки видны некие модули расстояний между центрами кадастровых кварталов многоэтажных жилых зданий.

Закономерности мало и средне этажной застройки. Из-за малой численности кадастровых кварталов этой подзоны (рис. 3) было получено трехчленное уравнение вида

$$
\begin{gathered}
y=y_{1}+y_{2}+y_{3}, \\
y_{1}=11200,478, y_{2}=4,57777 \cdot 10^{-136} x^{34,26625}, \\
y_{3}=-6,87315 \cdot 10^{-96} x^{32,40892} \exp \left(-0,010776 x^{1,00311}\right) \cos (\pi x / 645,07738-2,41219),
\end{gathered}
$$

у которой адекватность дошла до уровня «сверхсильная»с коэффициентом корреляции 0,9609.

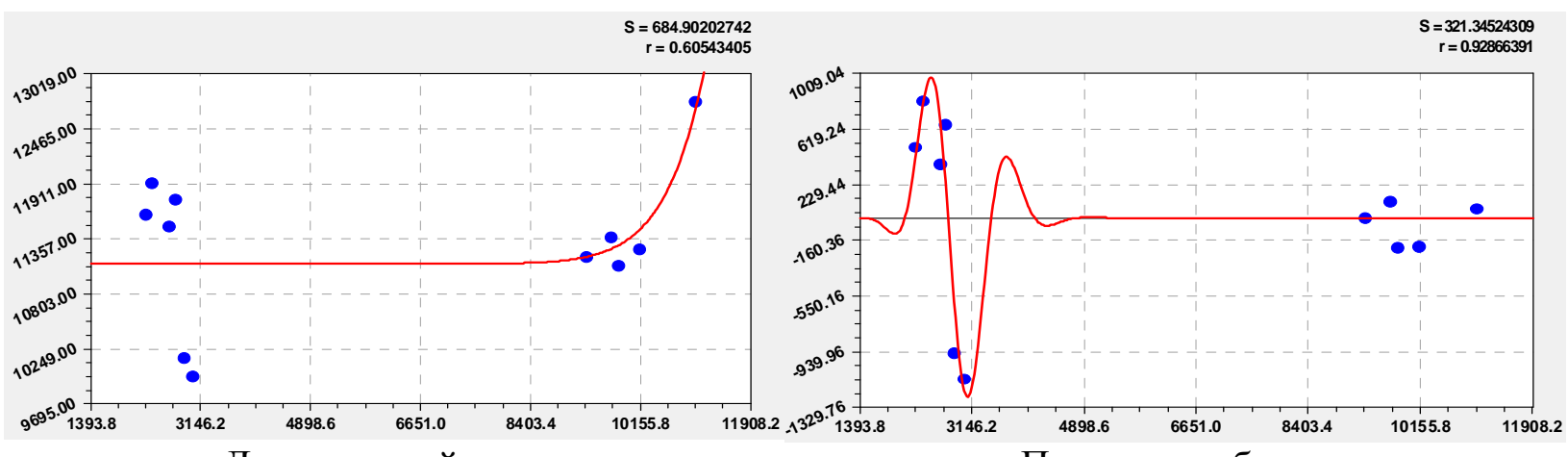

Двухчленный тренд

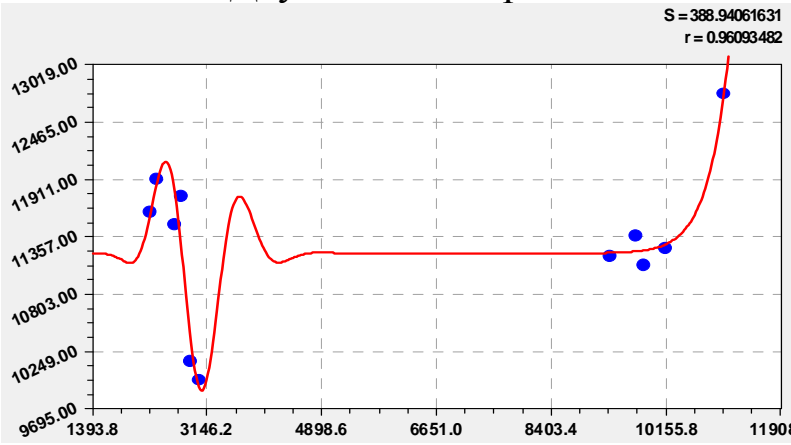

График модели (3)

Первое колебание

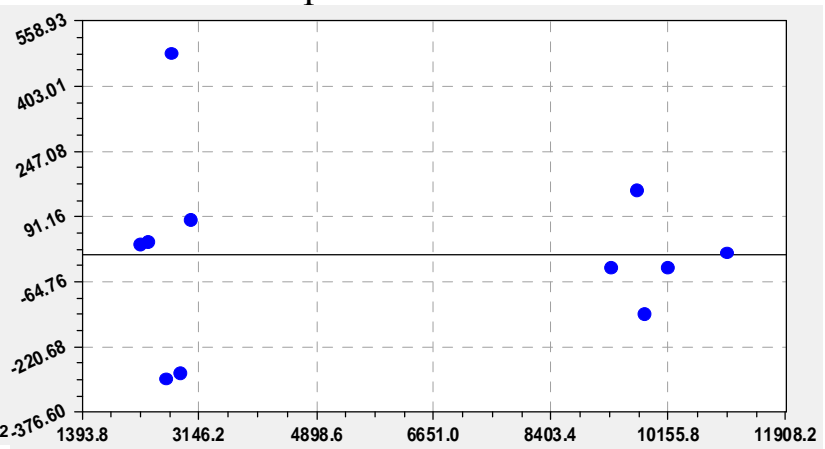

Остатки после модели (3)

Рисунок 3. Графики составляющих закономерности по мало и средне этажной застройке

Пустота между кластерами кадастровых кварталов показывает, что в центральной зоне города произошла значительная замена на многоэтажные жилые здания. Со временем левая волна также будет исключена, на месте мало и средне этажной застройки появятся многоэтажки.

Закономерности индивидуальной застройки. Модель (1) с параметрами для подзоны индивидуальной застройки также дана в таблице 3, и по вычислительным возможностям программной среды CurveExpert-1.40 (рис. 4) она имеет вид

$$
y=y_{1}+y_{2}+y_{3}+y_{4}+y_{5},
$$

$y_{1}=-145606,893, y_{2}=133282,017 x^{0,018109}$, 


$$
\begin{aligned}
& y_{3}=-3093,40746 \cos \left(\pi x /\left(1070,21330+0,0022140 x^{1,38727}\right)-3,53426\right), \\
& y_{4}=-2,16535 \cdot 10^{-95} x^{31,41117} \exp (-0,0083819 x) \cos (\pi x / 489,00766-0,74711), \\
& y_{5}=2,01387 \cdot 10^{-85} x^{28,08977} \exp \left(-0,0072397 x^{0,99942}\right) \times \\
& \times \cos \left(\pi x /\left(287,48554-0,0036619 x^{1,13629}\right)+3,35068\right) .
\end{aligned}
$$

Дополнительные вейвлеты появляются по остаткам от предыдущего колебания (рис. 4 и рис. 5). Поэтому адекватность общей модели станет выше коэффициента корреляции модели (4), равного 0,8695. Три волны уравнения (4) получаются с постоянным модулем длины волны поперек реки Малая Кокшага $2 \times 489,00766 \approx 1000$ м и переменными модулями, у которых начальные значения равны $2 \times 1070,21330 \approx 2140$ м и $2 \times 287,48554 \approx 575$ м. Из данных таблицы 3 видно, что максимальный модуль равен 10830 м, а минимальный модуль равен 60 м.
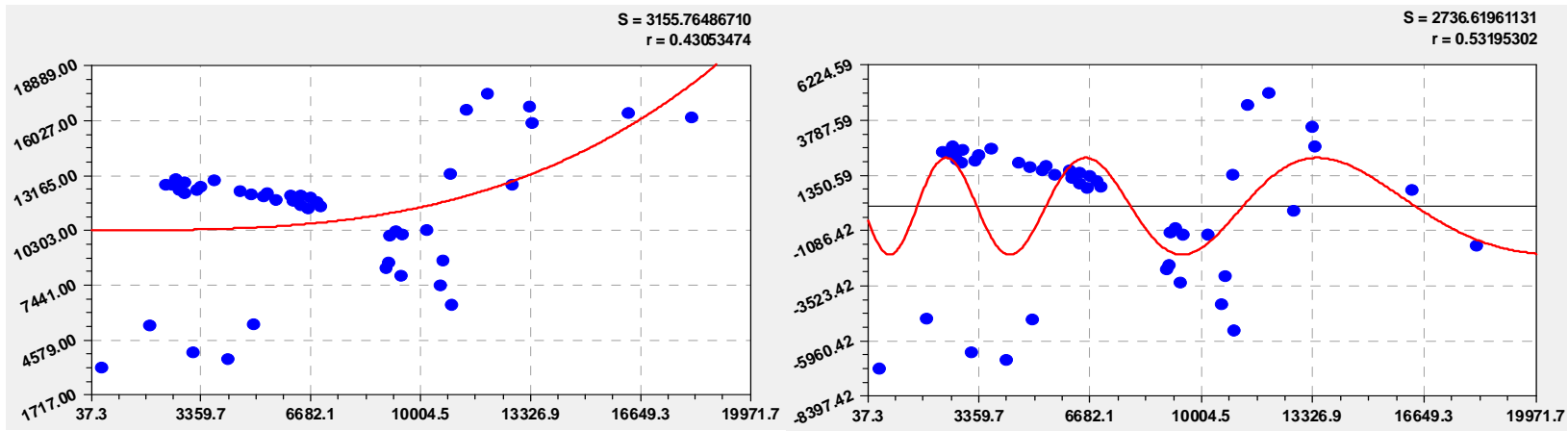

Двухчленный тренд
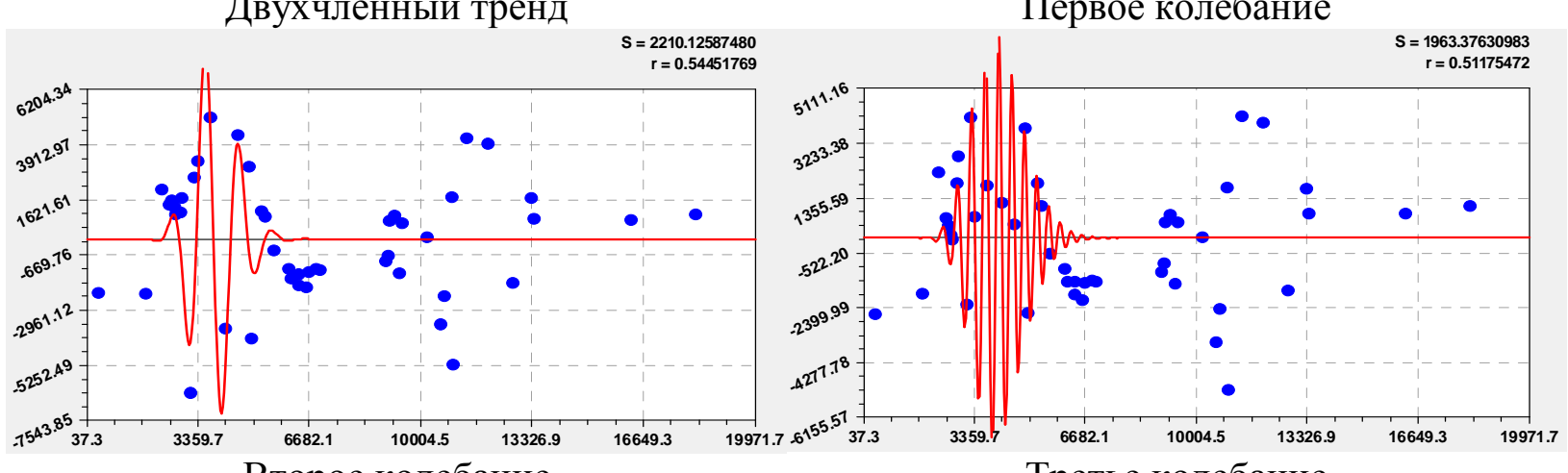

Второе колебание

Третье колебание

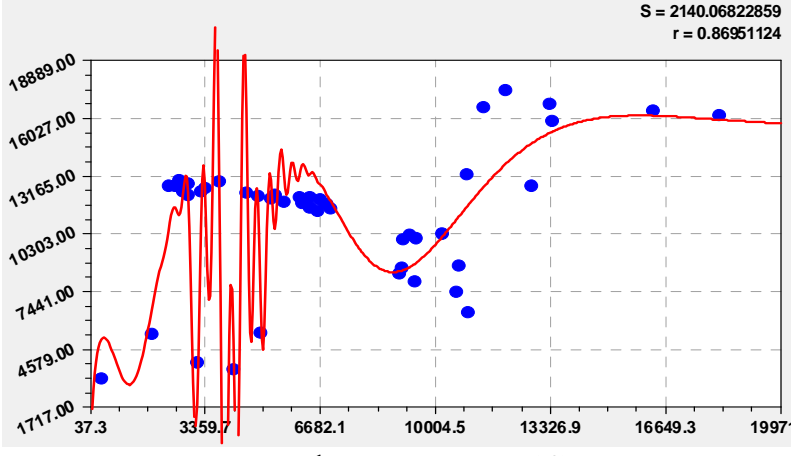

График модели (4)

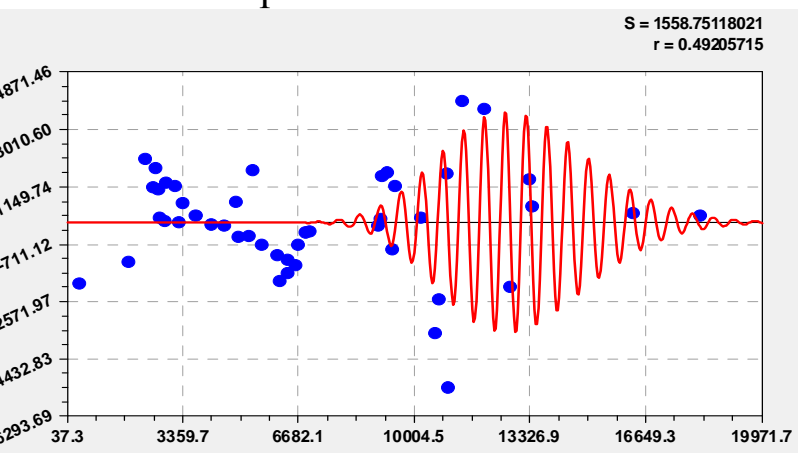

Четвертое колебание

Рисунок 4. Графики составляющих закономерности индивидуальной застройки

Из рисунка 4 видно, что наибольшие возмущения индивидуальной застройки наблюдается в западной части города Йошкар-Ола. Здесь происходит замена на многоэтажную застройку. 
Дополнительные вейвлеты имеют коэффициент корреляции (табл. 3) от 0,3466 до 0,6784. Этот факт показывает, что в Йошкар-Оле до сих пор значимы волновые закономерности распределения индивидуальной застройки. И это обстоятельство пока дает городу привлекательность. За последние 10 лет многоэтажная застройка получила современную архитектуру, значимое разнообразие архитектурных форм жилых и общественных зданий. Поэтому новые многоэтажные застройки резко отличаются от монотонности советских пяти и девятиэтажек.
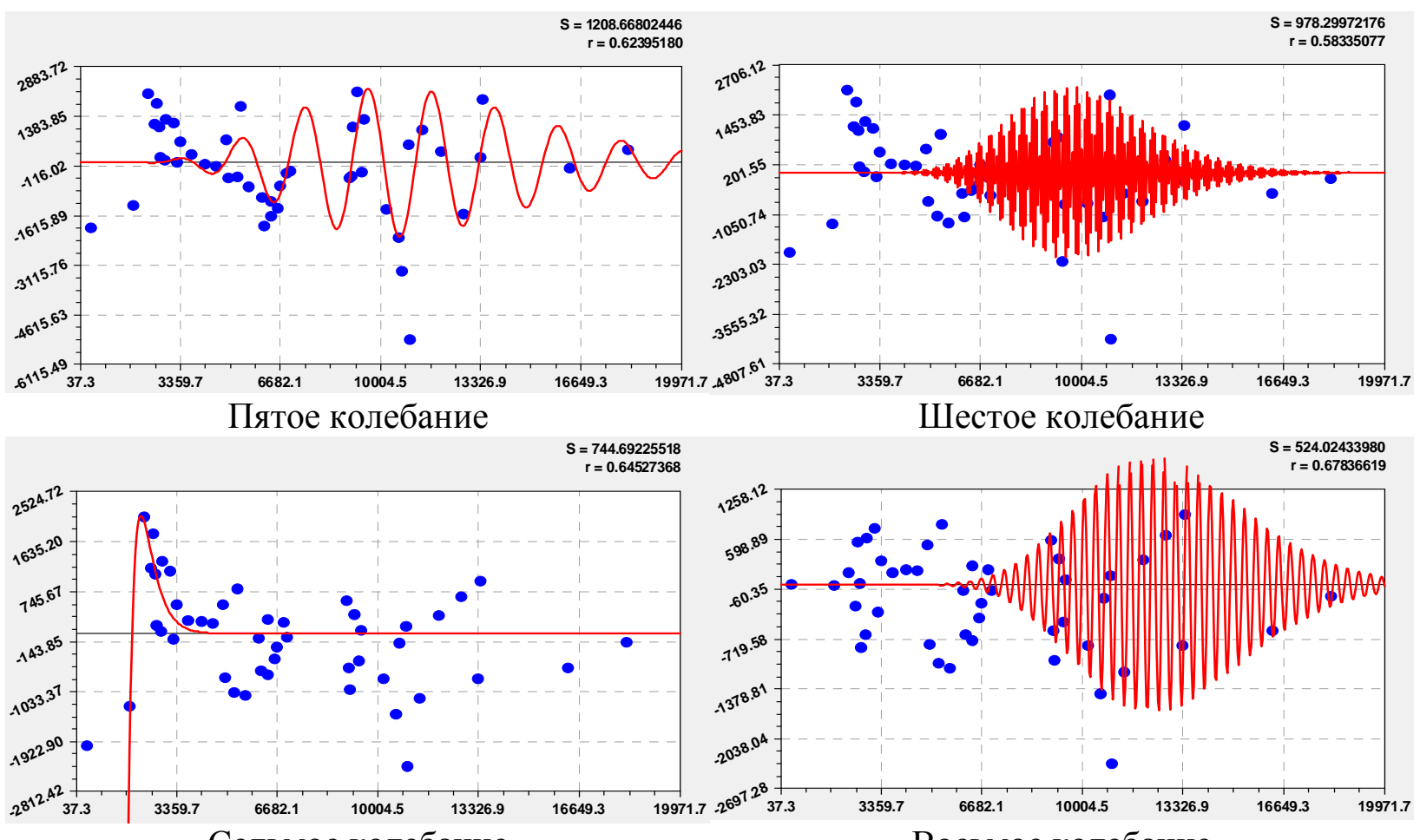

Седьмое колебание

Восьмое колебание

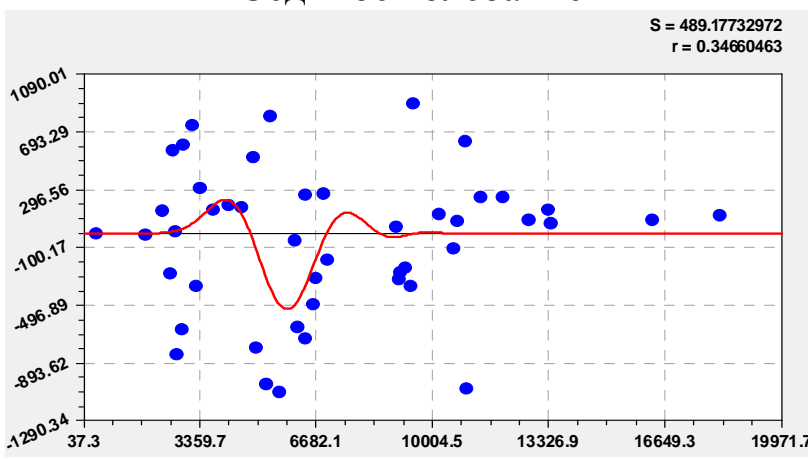

Девятое колебание

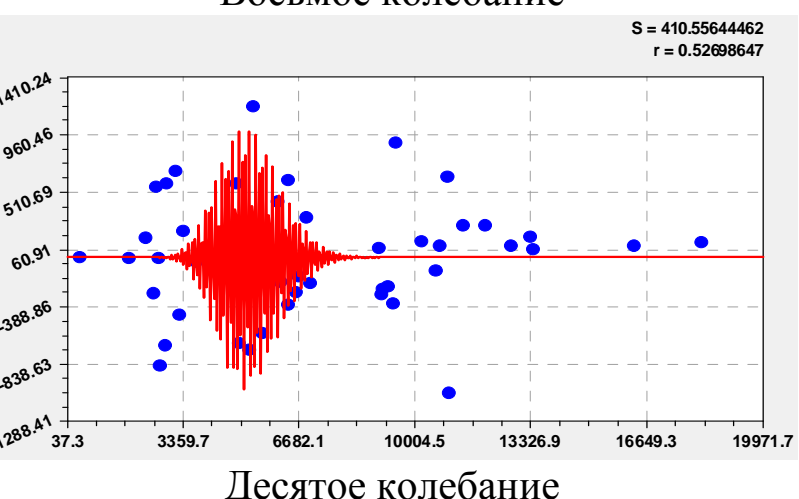

Рисунок 5. Графики дополнительных вейвлетов у закономерности индивидуальной застройки

Характер волновых составляющих показывает особенности замены. Например, седьмое колебание на рисунке 5 показывает, что на краю черты города резкое колебание центров кадастровых кварталов у индивидуальной застройки. Она резко переходит в многоэтажную застройку.

Закономерности распределения садово-дачных участков. Кадастровые квартала у этой подзоны всего шесть. Но они расположены в городе весьма удачно, создавая одно мощное колебательное возмущение поперек реки по всей площади города Йошкар-Ола.

После структурно-параметрической идентификации модели (1) была получена формула

$$
y=y_{1}+y_{2},
$$




$$
\begin{aligned}
& y_{1}=8,44488 \cdot 10^{-10} x^{3,66910} \exp \left(-0,00037550 x^{0,99996}\right), \\
& y_{2}=0,0020020 x^{1,84433} \exp (-0,00042064 x) \cos (\pi x / 618,85012-3,56137),
\end{aligned}
$$

у ней из-за малого количества точек адекватность дошла до коэффициента корреляции 1,0000.

Здесь первый член является биотехническим законом в полной форме. Он, в отличие от среднестатистического значения предыдущих уравнений, показывает высокую динамичность.

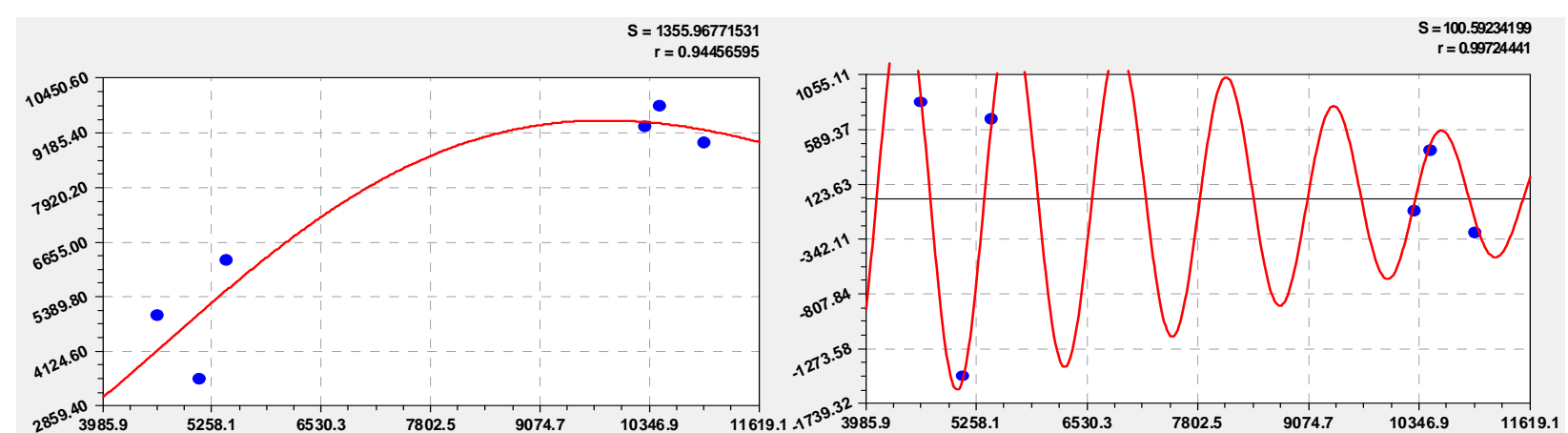

Одночленный тренд

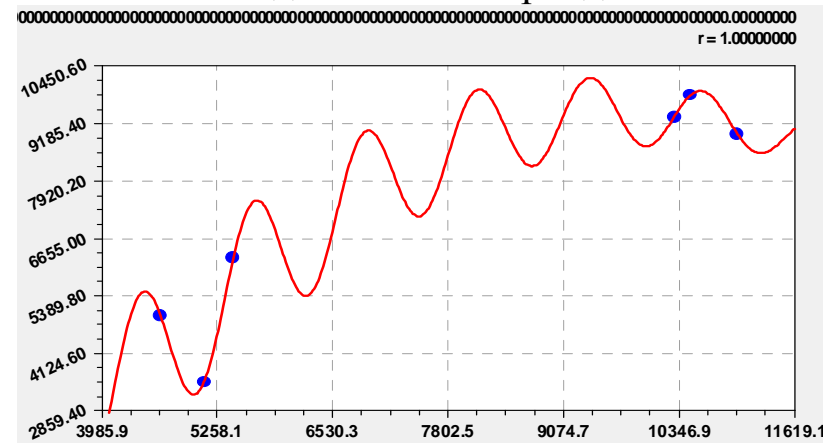

График модели (5)
Первое колебание

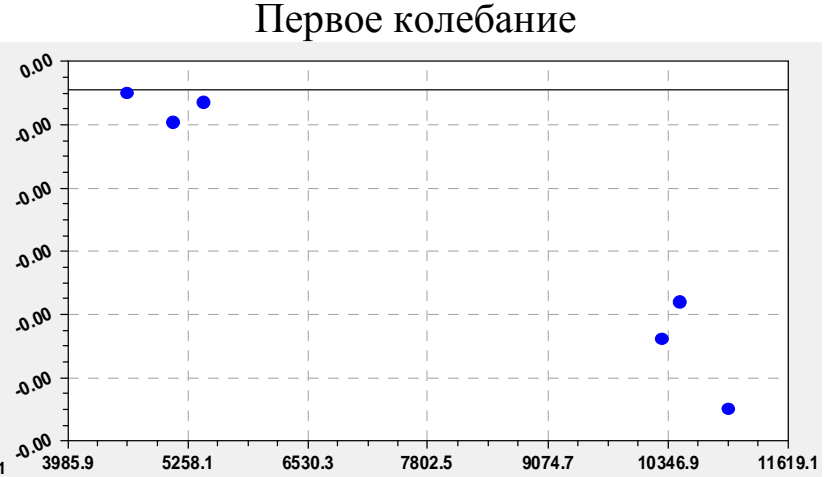

Остатки после модели (5)

Рисунок 6. Графики составляющих закономерности по садово-дачным участкам

Остатки от (5) близки к нулю, но показывают четкую закономерность убывания по закону спада. Для повышения точности статистического моделирования нужно снижать погрешность картографических измерений в ГИС «Карта-2011».

Заключение. Выявленные по статистическим данным городской среды биотехнические закономерности позволяют лучше понять складывающуюся во времени эволюции города структуру и функции отдельных подзон жилой зоны города. Достоинством волновых уравнений является возможность их применения в различных прогнозных расчетах. Они позволяют создать имитационную модель распределения центров кадастровых кварталов, а также перехода от индивидуальной застройки к многоэтажным зданиям. Знание таких закономерностей распределения параметров кадастровых кварталов позволит осознанно подойти к архитектурнопланировочным решениям, а это повысит в будущем комфортность городской среды.

\section{Список литературы}

1. Мазуркин П.М. Биокаркас территории: учеб. пос. с грифом УМО РАЕ. Йошкар-Ола: Поволжский ГТУ, 2013. 156 с. 
2. Мазуркин П.М. Динамика землепользования субъекта федерации // Землеустройство и кадастры: проблемы и пути их решения. Матер. Междунар. науно-практ. конф. в рамках пленарного засед. Совета УМО вузов по образ. в области землеустройства и кадастров / Под общ. ред. В.В. Вершинина. М.: ГУЗ, 2013. С. 94-99.

3. Мазуркин П.М. Коррелятивная вариация: учеб. пос. с грифомУМО РАЕ. Йошкар-Ола: Поволжский ГТУ, 2013. 120 с.

4. Мазуркин П.М. Прогноз землепользования в России // Землеустройство и кадастр недвижимости: проблем и пути их решения. Матер. научно-практ форума, посв. 235-летию со дня основания Госуд. ун-та по землеустройству / Под общ. ред. С.Н. Волкова, В.В. Вершинина. М.: ГУЗ, 2014. С. 61-67.

5. Мазуркин П.М. Тенденции землепользования в России // Модернизация системы управления объектами недвижимости: сб. научн. тр. I междунар. науч.-практ. конф. 22-23 ок-тября 2014 г., Пенза: ПГУАС, 2014. С. 109-113.

6. Мазуркин П.М. Экологический баланс территории: учеб. пос. с грифом УМО РАЕ. Йошкар-Ола: Поволжский ГТУ, 2013. 152 с.

7. Мазуркин П.М., Фадеев А.Н. Геоинформационные системы земельного кадастра, лесного реестра и особо охраняемых территорий // Современные проблемы науки и образования. № 4. 2009. C.69-75.

8. Мазуркин П.М., Кудряшова А.И., Фадеев А.Н. Вейвлет-анализ распределений центров кадастровых кварталов города // Землеустройство, кадастр и мониторинг земель. 2015. №8. с. 61-70.

9. Мазуркин П.М., Кудряшова А.И., Фадеев А.Н. Закономерности распределения кадастровых участков города Йошкар-Ола // Труды Поволжского ГТУ. Сер.: Технологическая. Вып. 3. Йошкар-ола: ПГТУ, 2015. С.259-263. 